\title{
Um poeta brasileiro no exílio: duas obras de Mario de Artagão escritas e editadas em Lisboa
}

\author{
A Brazilian poet in exile: Two works of Mario de Artagão written and edited in Lisbon
}

\author{
Francisco DAS NEVES AlVES \\ Universidade Federal do Rio Grande - Rio Grande - Rio Grande do Sul - Brasil
}

Dr

\begin{abstract}
Resumo: Análise da produção literária do poeta Mario de Artagão, durante os anos finais de sua vida, escrita no exílio na cidade de Lisboa, depois das ferrenhas perseguições políticas que sofreu no Brasil. Em terras portuguesas, o poeta abandonou a militância política, dedicandose exclusivamente à literatura, através da qual deixava emergir vários aspectos de sua visão de mundo. Na obra Rimas pagãs, junto de várias manifestações poéticas sentimentais, ele expressou a saudade de sua pátria, lembrando de sua história e de suas potencialidades, além de seus conterrâneos sul-rio-grandenses, bem como não esquecendo seus ideais monarquistas. E, em seu derradeiro livro, Feras à solta, trazia seu espírito anticlerical e suas preocupações de natureza social.
\end{abstract}

Palavras-chave: Literatura; História; Mario de Artagão; Monarquia

\begin{abstract}
Analysis of the literary production of the poet Mario de Artagão, during the final years of his life, written in exile in the city of Lisbon, after fierce political persecution he suffered in Brazil. In Portuguese lands, the poet abandoned political activism, devoting himself exclusively to literature, through which let emerge various aspects of their worldview. In work Rimas pagãs, from various sentimental poetic expressions, he expressed nostalgia for his homeland, recalling its history and its potential, and its sul-rio-grandenses countrymen, and not forgetting his ideals royalists. And in his last book, Feras à solta, bringing its anticlerical spirit and its social concerns.
\end{abstract}

Keywords: Literature; History; Mario de Artagão; Monarchy

As sólidas inter-relações históricas constituíram fator essencial para uma constante interação cultural entre Brasil e Portugal, não só à época colonial, como também após a emancipação política brasileira. Apesar da ascendência emanada das potências imperialistas, notadamente a francesa e a britânica, no que tange à formação cultural lusa e brasileira, como metrópole e colônia e depois como países independentes, as duas nações iriam também exercer mútuas influências entre si. Tais permutas recíprocas no campo cultural iriam se manifestar fortemente através do intercâmbio de intelectuais de lado a lado, havendo uma constante corrente migratória transoceânica de escritores em geral, poetas, jornalistas, caricaturistas e tantos outros amantes e profissionais das letras. Nesse cenário de mútuas trocas esteve inserido o poeta e jornalista brasileiro e sul-rio-grandense Antônio da Costa Corrêa Leite Filho, que ficaria mais conhecido pelo pseudônimo Mario de Artagão, adotado em suas lides literárias.
Mario de Artagão nasceu na cidade do Rio Grande, a 16 de dezembro de 1866. Pertencia à família abastada vinculada às atividades mercantis, o que permitiu a execução de seus estudos na Europa, concluindo o curso de Humanidades no Porto e frequentando cursos superiores em Paris e em Hamburgo, na qual ingressou na Faculdade de Filosofia e Direito, bacharelando-se na primeira área, mas não completando o curso jurídico. De volta ao Brasil, foi representante do empreendimento familiar no Recife e no Rio de Janeiro, lugares onde também deu vez a seus pendores intelectuais, até retornar à sua cidade natal para assumir a direção da firma comercial Leite \& Cia. Ltda. Como intelectual, exerceu significativa carreira de jornalista, tendo escrito na Tribuna Liberal do Rio de Janeiro, no Correio Mercantil da localidade gaúcha de Pelotas, no Artista, no Echo do Sul e no Rio Grande do Sul, todos da cidade onde nasceu. Foi também no Rio Grande que fundou o periódico A Actualidade (1892-1893) no qual sustentou suas ideias monarquistas 
em plena oposição à ditadura republicana castilhista que dominava o Rio Grande do Sul à época, o que acarretaria ferrenha perseguição política ao escritor.

Representando o típico intelectual de seu tempo, Artagão atuou em múltiplas áreas. Afora poeta e jornalista, foi também professor, filósofo, conferencista e teatrólogo. Era poliglota, dominando além da língua materna, o inglês, o francês, o espanhol, o alemão e o italiano. Foi membro-fundador da Academia Rio-Grandense de Letras, em 1902, além de ter sido membro de academias literárias em Paris e em Hamburgo. Enquanto permaneceu no Brasil, inaugurou sua vida literária com o lançamento de As infernais, em 1889, que já contaria com uma segunda edição no ano seguinte, e deu prosseguimento a tal carreira com a edição de Psaltério (1894), Psaltério na quermesse (1896), Janina (1900) e Música sacra (1901). Além disso, contribuiu com poemas para o Almanaque Literário e Estático do Rio Grande do Sul, o Almanaque Popular Brasileiro e o Anuário do Estado do Rio Grande do Sul (BLAKE, 1900, p.242-243; MARTINS, 1978, p.308-309; NEVES, 1987, p.51-53; e VILLAS-BÔAS, 1974, p. 268).

Tendo em vista sua militância política monarquista, Mario de Artagão foi alvo das típicas perseguições sofridas por intelectuais nos primeiros tempos da república brasileira. Os modelos autoritários na esfera federal e especificamente o de Júlio de Castilhos no âmbito estadual desagradaram profundamente os defensores de estruturas mais liberais e/ou aqueles que foram desalojados do poder com a mudança da forma de governo. Dentre os descontentes, os monarquistas buscaram também arregimentar forças no combate ao novo regime. Tais embates se deram em escala maior por meios de intelectuais e nesse quadro agiu o escritor rio-grandense que se colocou não só na oposição, mas também na resistência aos governantes. Buscando sustentar sua convicção monárquica, o autor enfrentou enquanto pode o cerceamento, a censura e a repressão, colocando-se como um dos arautos daqueles que estavam em desarmonia em relação à situação governativa. A seu modo, Artagão representou uma daquelas tantas vozes discordantes que viriam muitas vezes a serem caladas e, mais tarde, apagadas da memória política gaúcha pela imposição do modelo castilhistaborgista, predominante por décadas a fio na conjuntura sul-rio-grandense (ALVES, 2012, p. 369).

Tamanhas perseguições fizeram com que Artagão tivesse de abandonar o jornalismo (SODRÉ, 1999, p. 263) e chegasse a ter de refugiar-se por oito meses no consulado inglês. Tais desgostos com os rumos autoritários predominantes, acrescidos ao falecimento de seu pai, constituiriam acontecimentos que fizeram com que o poeta acabasse por vender o valioso patrimônio familiar e optasse por um autoexílio em terras portuguesas, tendo se mudado para Lisboa, em 1905, permanecendo ali até o seu falecimento em 16 de agosto de 1937. O exílio acabaria se tornando adoção e o escritor gaúcho elegeria Portugal, berço de seu pai, como o seu novo lar. Intelectualmente, abandonaria a carreira de jornalista militante, evitando qualquer comentário e guardando o mais profundo silêncio sobre a política da sua terra natal, preferindo não se ocupar das facções que governavam o Brasil (SARMENTO, 1907, p. 494).

Além de ter abandonado o debate político, nos primeiros anos em Portugal, cuidando da adaptação de sua família, o escritor viu-se abstraído e quase desquitado da pena, com a qual vivera intimamente por tantos anos e até, ao menos na aparência, amuado da convivência ativa com a poesia (FREITAS, 1908, p. 352). Passado algum tempo de sua instalação na nova e adotiva pátria, Artagão voltaria a dar vez e voz à sua verve literária. Ele lançou uma segunda edição de Janina (1907) e de Psaltério (1912), bem como uma terceira edição de As infernais (1914). Além disso, publicou os poemas No rastro da águias (1925) e Rimas pagãs (1933), a conferência Helláda ninho dos deuses (1934) e o drama Feras à solta (1936). Ainda são citadas em suas próprias publicações, como obras inéditas do autor, o drama $A$ taça, o romance $O$ senhor deputado, o poema sociológico Crepe e o estudo Darwinismo e deísmo.

Ao longo de sua atuação literária, o autor manifestaria as várias etapas de sua formação estudantil e acadêmica, bem como suas cargas de leitura e vivências na Europa (ALVES, 2011, p. 51). Dessa forma, foi no continente europeu que Mario de Artagão recebeu a educação literária que o extremou da cultura gaúcha em geral, de modo que a leitura de seus versos tinha por significado respirar o clima espiritual europeu, percorrer velhos caminhos do Ocidente e sentir o pathos lírico de povos mais velhos, mais próximos da matriz latina. Apesar de um germanismo inicial, suas maiores influências ficariam marcadas pela interpretação de autores portugueses, a partir dos quais deu arras ao seu inconformismo e à sua revolta, da qual passaria ao saudosismo. Foi um pouco de tudo, tendo misturado germanismo e lusitanismo, religiosidade e ateísmo, suavidade e rudeza, constituindo uma curiosa figura, pois conseguia ser ao mesmo tempo rebelde e inquieto, monarquista em política e darwinista em ciência (CESAR, 2006, p. 317-320). Esse ecletismo do escritor é observável a partir da análise de duas de suas derradeiras obras - Rimas pagãs e Feras à solta, escritas durante seu autoexílio em terras lisbonenses.

O livro Rimas pagãs foi publicado em 1933, nas Oficinas da Sociedade Nacional de Tipografia em Lisboa. Na parte introdutória da obra, intitulada "Asas despertas", o autor fazia uma "Invocação à musa", referindo-se à inspiração para elaborar seus escritos e lembrava seu 
afastamento das lides literárias por algum tempo, além da diminuição no seu ritmo de produtividade durante seu autoexílio em terras portuguesas, mormente, se comparado com a intensidade criativa de seus anos iniciais como escritor. Nesse sentido, Artagão dizia que andava de todos esquecido, reconhecendo que a culpa para tanto era sua, mas, embora tarde, a musa o tinha de volta, como outrora, turbado pelo hálito florido de tal fonte inspiradora. Ele afirmava ainda que queria achar o céu perdido e de novo encontrar a mesma aurora, na ardente e clara vibração sonora do seu lírico verso adormecido. O poeta invocava a musa, insaciado e cheio de amor, numa febre de anseios fortes, buscando a curva dos sagrados flancos daquela figura mítica, imaginando que ela, como mulher, não se importaria que ele já possuísse alguns cabelos brancos (ARTAGÃO, 1933, p. 7).

Os sentimentos amorosos de Artagão afloravam na primeira parte de Rimas pagãs, intitulada "Diálogos cor de rosa", composta essencialmente de conversas travadas entre "Ele" e "Ela", trazendo em si o significado das interrelações masculino - feminino e variadas facetas dos encontros e desencontros da vida a dois. Em "O supremo amor", o diálogo traduzia o arrependimento de um homem que abandonara sua amada e buscava o perdão da mesma que permanecia irredutível, culminando com a descoberta da parte dele que daquela relação resultara um filho. "Dominó lilás", por sua vez, trazia um homem e uma mulher já não tão jovens, que conversavam sobre presente e passado, buscando superar sem sucesso uma traição. Já "O eterno fim" mostrava o desgaste das relações matrimoniais, revelando o cansaço que o passar do tempo e a rotina provocavam no seio do casamento. Em contrapartida, "O meu relógio" revelava a superação de tais inconvenientes na vida conjugal, obtida por meio da compreensão mútua. "Encontro tardio", por sua vez, retornava à amargura de duas pessoas que, apesar de enamoradas, seguiram destinos diferentes, ela casara e ele, que permanecera solteiro, buscava, sem sucesso, retomar o passado perdido. Uma paixão languida aparecia em " $\mathrm{O}$ casaco de peles", que aludia aos mistérios indissolúveis envoltos na escolha entre a aparência física e o verdadeiro amor. Finalmente, "Num salão de antiguidades", abordava as relações homem - mulher, com base no antagonismo entre uma vida baseada nos pecados mortais e carnais e outra, alicerçada num amor "eterno, nostálgico e bendito" (ARTAGÃO, 1933, p. 9-49).

"Conversando com os deuses" servia de título à segunda parte de Rimas pagãs, na qual Artagão versava sobre uma de suas paixões voltada às mitologias e à antiguidade, sem deixar de associar tais incursões à sua inspiração amorosa. No primeiro poema, "A aposta de Frinéia", a bela e inspiradora cortesã helênica dialogava com uma turba, servindo a conversa de cenário para a participação de várias deidades e personagens da Grécia Antiga, e para a aclamação da superioridade do feminino sobre o masculino. A seguir o poeta trazia "O sonho do faraó" no qual, em meio à participação de várias entidades da mitologia egípcia, encenava a entrada de um saqueador na tumba do soberano, o qual não se importava se o invasor pilhasse todas as suas riquezas, desde que lhe poupasse o vaso com as suas vísceras, pois ali estavam o seu coração e o da mais linda mulher que amara em todo o Egito. Já em "A história de Narciso", o escritor, mais uma vez lançando mão de vários seres míticos, contava em versos a vida, a morte e o renascimento em forma de flor deste personagem. "Zeus munificente", por sua vez, retratava uma passagem na qual a divindade máxima grega concedia a dois anciãos que lhe haviam dado guarida o pedido de viverem juntos para sempre, transformando-os em árvores, desejo também manifesto por Artagão para si próprio em relação à sua amada (ARTAGÃO, 1933, p. 51-72).

Rimas pagãs prosseguia com "As minhas sonatas", a terceira parte, na qual predominavam incursões e devaneios do autor em relação a suas próprias memórias. Em "O estojo misterioso", o poeta lembrava a sua época de estudante na Alemanha, fazendo alusão a uma imaginária incursão arqueológica, na qual encontrava o crânio de uma mulher que sonhara viver para sempre. Já no poema "Na praia", em meio ao mar, às estrelas e às areias, Artagão rememorava o perfume de sua amada junto ao ambiente balnear, algo extremamente comum para quem vivera em lugares visceralmente ligados às águas, como Rio Grande, Rio de Janeiro, Recife e Lisboa. Em "Resposta à tua carta", o escritor associava as missivas de sua amada com o perfume das flores. A seguir, apresentava "Nervos" no qual traçava analogias entre as práticas comezinhas da maquiagem feminina e os contratempos da vida a dois. A comparação também predominava em "A ave ferida", desta vez entre um pássaro abatido e as fraquezas femininas. "Embriaguez cor de rosa" mostrava uma paixão ebriosa em meio às belezas da natureza e das mulheres. Em seguida, apresentava "Berço de espumas" no qual descrevia a beleza feminina ao longo dos tempos, utilizando-se desde preceitos da cultura grega clássica até o darwinismo. "Esfinge" abordava o desejo pelo beijo de uma mulher que resistia, apesar da passagem do tempo e do fim da mocidade. No próximo poema, "O verbo amar", o autor abordava um de seus temas de preferência, mas, além do amor conjugal, lembrava também os sentimentos de amor à pátria, tanto a de nascimento quanto a adotiva. Logo a seguir escrevia "Sofreguidão", um apelo para que a amada não fosse embora, "A ilha encantada", na qual pretendia levar sua alma gêmea para um lugar utópico, "Pastoral ao piano", retratando o namoro em um baile, "Temporal 
desfeito", no qual evitava que a namorada se expusesse à chuva, "Amor silencioso", referindo-se a um romance secreto e "O voo nupcial", em que fazia uma analogia entre a vida amorosa das mulheres e o comportamento das abelhas em uma colmeia (ARTAGÃO, 1933, p. 73-112).

Foi na última parte de Rimas pagãs, denominada "Pátria distante", que Mario de Artagão realizou algumas breves incursões às suas vivências anteriores ao exílio, revelando certas recordações da nação que tivera de abandonar. O saudosismo do poeta se manifestava com veemência como no caso do poema "Terra à vista", no qual descrevia as grandezas brasileiras, notadamente no que tange à natureza e à geografia de sua "pátria amada":

No voo clangoroso, abrindo as asas francas, Exaltadas, febris, imensamente brancas, Quanta vez a saudade, esse albatroz errante, Se faz comigo ao mar com rumo ao sul distante!

E nunca se transvia! É para achar os ninhos, Que Deus manda espalhar os sóis pelos caminhos... Por isso a flamejar, fincada no infinito, Há uma cruz!... Mas esta em vez de ser de granito Como as cruzes ducais nos velhos mausoléus, É um braço de luz, apontando nos céus A estrada que vai ter de quebrada em quebrada, Ao berço onde floreja a minha Pátria amada!...

Mas quando não houvesse um astro na amplidão, E quando tudo fosse angústia e dispersão, Bastaria, de longe, ó rútilo Amazonas, Auscultar-te os pulmões quando a bramir ressonas! Frente a frente, insubmisso, e desafiando o mar Que raivoso jurou não te deixar passar, Espumejas tão alto e investes com tal ânsia, Que longe, sempre a uivar, muito longe, à distância, Julgo, assombrado, ouvir nas tuas pulsações Os berros colossais dum bando de leões! Contigo em convulsões, contigo por meu guia, Num largo voo astral, facilmente acharia, Cintada pela espuma, essa ilharga sagrada Dos fulvos areais da minha Pátria amada! (ARTAGÃO, 1933, p. 115-116)

Por meio dos versos intitulados "O primeiro beijo", o escritor fazia uma associação entre sua "Pátria distante" e aquela que adotara como novo lar e na qual já residia há quase três décadas. Nesse sentido, Artagão buscava reproduzir através da poesia a intersecção entre Portugal e Brasil, reconstruindo o encontro do luso colonizador com os habitantes originais dos trópicos. Ainda que chamasse os lusitanos de invasores, o poeta apresentava uma versão romantizada da ocupação das terras brasileiras e a formação de um novo povo, o qual teria se originado de uma miscigenação pacífica, resultado de uma supostamente harmoniosa união entre os brancos e as índias, abençoada por uma divindade que representava o amor:
Esplende uma manhã de claras vibrações! Toda a selva estremece. E pandos, os galeões, Vem poisar, um a um, como aves tresnoitadas, $\mathrm{Na}$ funda quietação das mornas enseadas!... Pisando o chão sagrado, o impávido invasor Vê que tudo esbraseia, em síncopes de amor!... E sob um céu pagão, atordoado de luz, Genufletindo, a orar, faz o sinal da cruz... A prece apenas dura o sopro dum instante! Olha em redor, inquieto... E um cheiro perturbante, Um cheiro de baunilha esperta-lhe um desejo Que começa num sonho e acaba por um beijo! Esbeltas pela praia ondulam convulsivas As formas nupciais das aimorés lascivas... Quer segui-las... E o bando, arisco, quase implume, Trasmonta o matagal num rastro de perfume... Quer inda ousar... e hesita! Estrídulo, fremente, Da selva densa, como um silvo de serpente, Vem-lhe cair aos pés um dardo envenenado... Não se perturba! Arranca o morrião amolgado, E apolínio, tranquilo, intrépido e viril Transfunde-se na luz daquele sol de abril... Vê depois espreitar por entre as perobeiras O mesmo bando em flor das caboclas trigueiras... Atira-lhes um beijo... Um beijo que desata Fulgurações mortais no coração da mata! Tudo entumece como um útero fecundo! Tudo estua e flameja! E no bambual profundo Pela primeira vez, despertos pelos ninhos, Os mansos jaçanãs vão servir de padrinhos Aos mais lindos, gentis e doces esposais Que Rudá jamais viu nas moitas tropicais! (ARTAGÃO, 1933, p. 117-118)

Como se elaborasse uma resposta a todas as correntes nacionalistas, xenófobas e anti-lusitanas que campearam pelo Brasil em diversas épocas, notadamente durante a implantação ditatorial da república, contra a qual tanto Mario de Artagão lutara, o poeta absolvia os colonizadores lusos de qualquer teor de violência durante a conquista da América meridional, apresentando mais uma vez a visão de um harmônico casamento inter-racial entre nobres portugueses e valentes indígenas, dando origem à briosa nação brasileira:

Deixai dormir no chão da nossa terra Por entre os bogaris, O tacape de guerra

Dos nossos sacrossantos guaranis! Deixai dormir a velha raiva injusta

Contra a radiosa estirpe, eterna e augusta

Dos príncipes de Avis!

Foi Deus que assim o quis!...

Um seio de tapuia

Não se conquista a golpes de montante!

Além de um beijo, pede uma aleluia

Que a envolva toda da cabeça aos pés!...

E foi assim que doce e provocante

Um beijo português 
Na febre irresistível dos sertões,

Sonoramente, manso e triunfal,

Desplumara uma entranha virginal

Na gestação dum povo de leões!

Não nego! Era estrangeiro

$\mathrm{O}$ beijo estonteador

Que fecundou à sombra do ingazeiro

A nossa raça eternamente em flor!

Mas um beijo de amor,

Quando temos na frente um corpo nu,

Não é... não é pecado!

Que o diga num espasmo de noivado

A morena e gentil Paraguaçu.

A nossa estirpe é essa! Ovários guaranis

Fecundados ao sol por capitães d'Avis!

E desse beijo audaz no fundo dos sertões

Um leão há de ser sempre o pai d'outros leões!

Há muitos povos que tiveram donos!

Mas no estertor dos látegos cruéis

Se todos foram filhos de colonos,

Nós fomos, afinal, filhos de reis!

(ARTAGÃO, 1933, p. 118-119)

As saudades de Artagão ficavam expressas também no poema "As duas bandeiras", no qual ele acabava por fazer uma comparação entre o Brasil da época monárquica e o outro, sob a égide da república. A bandeira figurativamente representava a nação brasileira, servindo para mais uma vez exaltar as exuberâncias do país tropical. As preferências monarquistas do poeta ficavam bem demarcadas no amplo destaque dado às vitórias do império brasileiro nos enfrentamentos bélicos que teve em relação a seus vizinhos platinos, lembrando as derrotas de paraguaios, argentinos e uruguaios diante das forças militares imperiais:

Insubmissas, febris, num halo de esplendor, Irmãs no voo, irmãs na glória, irmãs na cor, Flabelam no Brasil com asas condoreiras, Entre heróis e clarins, duas sacras bandeiras! Vistas de longe, em pleno azul, mordendo o espaço, Não se distingue bem se levam no regaço Os braços duma cruz apertando uma esfera, Ou um cinto apertando o seio à primavera! A esfera é armilar com cercadura d'astros, Tendo o mundo a seus pés e o infinito de rastros! Há flores nos beirais; e no alto, entre rubis, Fundindo o sangue azul no sangue dos tupis, Refulge uma coroa. Em maio, as alvoradas Inda apanham no chão as lágrimas choradas!... Foi ela, por tojais, no assalto das tocaias, Que andou domesticando as onças paraguaias!... $\mathrm{Na}$ abalada imperial com pulso de gigante Foi ela, a espumejar, heroica e palpitante Que arrancou aos covis, em manhãs luminosas, Essa pantera - o Oribe; e esse chacal, - o Rosas! (ARTAGÃO, 1933, p. 121)
Ainda que chegasse a também reconhecer alguns avanços sob a forma de governo republicana, mormente no que tange à expansão e à consolidação das fronteiras nacionais, citando algumas das disputas lindeiras nas quais o país esteve envolvido na virada do século XIX ao XX, Mario de Artagão não deixava de lembrar que alguns dos principais articuladores de tais vitórias brasileiras teriam sido políticos egressos da época imperial, como era o caso do principal deles e que, inclusive, mantinha o título nobiliárquico, mesmo após a queda monarquia, ficando conhecido como Barão do Rio Branco. Mas as filiações ideológicas do poeta ficavam ainda mais explícitas no encerramento dos versos, nos quais ele chegava a reconhecer o amor pátrio tanto pelo Brasil imperial quanto pelo republicano, mas sua preferência era pela bandeira que encerrava a coroa monárquica, em contraposição à república da espada, contra a qual tanto lutara e sofrera os efeitos do autoritarismo:

Se uma suspende a esfera, a outra, em campo azul, Suspende a luz dos sóis dispersos pelo Sul! E se a vemos gentil arrebanhando estrelas, Se a vemos marinhar aos céus para mantê-las, Não me espanta que altiva, irrompa nos sertões Arrebanhando o Acre, o Amapá e as Missões! Se a quereis procurar, buscai-a pelos ninhos Ou junto duma dor à beira dos caminhos! Mas ai, de quem ousar morder-lhe o nobre flanco! Se foi linda e sublime às mãos de um Rio Branco,

Não esquece jamais que sobre a nossa História Pairam águias reais nimbadas pela glória!

Tem uma no brasão os velhos sonhos meus; Tem a outra uma espada esburacando os céus! Mas seja uma coroa ou mesmo espadas nuas, Darei, de pé, cantando, a vida pelas duas! (ARTAGÃO, 1933, p. 122)

Finalmente, ao encerrar Rimas pagãs, Mario de Artagão, mantinha o espírito saudosista em relação à sua "Pátria distante", desta vez trazendo reminiscências de seu torrão natal, lembrando "O gaúcho", um representante típico da terra e da gente sul-rio-grandense. Este gaúcho do poeta reproduzia a figura que iria cada vez mais se tornar um verdadeiro estereótipo dos nascidos no Rio Grande do Sul, com destaque para a indumentária, os costumes e, fundamentalmente, o arquétipo do "centauro dos pampas", ou seja, o cavaleiro inseparável de sua montaria em suas lides campeiras. Mas, ao mesmo tempo, o escritor lembrava uma "alma heroica" do gaúcho, numa alusão a outra característica atribuída aos antigos habitantes das terras rio-grandenses, voltada a um espírito libertário, que fora condenado por quatro décadas de domínio de um regime ditatorial, o mesmo contra o qual Artagão se opusera e se rebelara nos primórdios da república e que, já nos anos trinta, parecia finalmente superado: 
Laço no tento, franco, de olhar vivo, Como um famoso cavaleiro andante, Lá vai o guasca intrépido e galante, Fundido em bronze, sobre o pingo esquivo!

Por essa pampa idílico e nativo, Onde o silêncio é morno e perturbante, Corre e sonha e lateja a todo instante A alma heroica do gaúcho altivo...

De poncho ao vento e de rebenque alçado, Enraivado de luz, transmonta o espaço!

E nesse voo audaz, desabalado,

Parece, numa fúria de vencê-las, Que vai, nervoso, derrubar no laço As manadas inquietas das estrelas!... (ARTAGÃO, 1933, p. 123)

Desse modo, o livro Rimas pagãs trazia em seu conteúdo várias facetas do eclético pensamento de Mario de Artagão. Apesar do predomínio dos versos voltados aos sentimentos mais íntimos, o poeta destinava também significativa parte da obra para dissertar sobre uma de suas predileções ligadas ao mundo antigo e, mais especificamente, às figuras mitológicas. Ainda que tivesse desistido das lutas político-partidárias, abandonando sua ativa militância ideológica através das páginas dos jornais, após adotar Lisboa como seu novo lar, a saudade falou mais alto e o escritor não deixaria de lembrar sua terra natal, fosse o Brasil como um todo, fosse o Rio Grande do Sul em particular. E, ainda que nas entrelinhas, os poemas que serviam para lembrar a pátria distante no tempo e no espaço, traziam pequenos vestígios da época de lutas por ele empreendidas. Outras angústias e preocupações do autor viriam à tona em Feras à solta, sua derradeira obra publicada durante o autoexílio.

Foi já no último ano de sua vida que Mario de Artagão trouxe a público Feras à solta, livro no qual expressaria facetas mais contundentes de seu pensamento, com várias incursões a preceitos anticlericais e a uma aguçada preocupação de natureza social. Tal obra foi editada em Lisboa, no ano de 1936, pela Gráfica Portuguesa, e apresentava, em essência, as conversas entre dois homens. No primeiro capítulo, denominado "Na Tasca", era descrita uma noite de Natal, em um bairro excêntrico de uma grande cidade europeia, com um inverno fustigante, na qual se encontraram Patrício e Marcos, recolhendose a uma tasca de travejamento desconjuntado. Ambos desenvolviam diálogos que o escritor expressava na forma de versos. O primeiro era um religioso que mitigava suas agruras através da fé, o segundo, um incrédulo e cético para com os assuntos divinos e um revoltado com as desigualdades sociais. Na conversa, Marcos lastimava sua sorte e situação de penúria, afirmando ao conhecido que não deveria pensar que ele sempre fora o escarro de um esgoto, pois chegara a ter no brasão quartéis de bom costado e um bispo por avô, em estirpe sem igual, mais nobre que a dos reis na conquista do Graal. Mas acabara chegando àquela situação de um farrapo que chafurdava na lama, sem pão para comer e sem cama (ARTAGÃO, 1936, p. 5-6).

Em seguida, Marcos fazia uma longa explanação sobre os caminhos e descaminhos de sua vida e suas formas de pensar e agir. Declarava que, apesar do sangue azul nas veias, lhe mordiam por dentro as desgraças alheias, como um sentimental idiota, ou um Quixote moderno, com pena dos pulmões que tossiam pelo inverno. Afirmava ainda que lera toda a Enciclopédia e Voltaire, o maldito, vindo um dia a despertar de bruços no infinito e, a cavalo no sonho, andar de astro em astro, a medir, a sondar, a farejar o rastro de um princípio sem fim. Dizia ainda que auscultara sem cansaço as válvulas senis do coração do espaço, e tudo cheirava a um açougue enorme, no qual, tragicamente, a morte nunca dormia e onde nada vira ou palpara que lhe desse um sentido forte, sacro, imortal, de um mundo concebido, só havendo em tudo uma luta vil e sem heróis. Comparava a existência a um casebre que haveria de cair, escanzelado e impuro, como caía na esterqueira um fruto de maduro, não passando disso a vida e a "harmonia celeste", arrematava com ironia (ARTAGÃO, 1936, p. 7).

Tendo em vista tal descrição, Patrício argumentava que o tempo fora agreste e torvo para eles, mas, embora também faminto, ele não sentia aquela mesma angústia de viver. Diante de tal asserção, Marcos salientava seu espírito de revolta, exclamando que o conformismo do outro se devia ao fato de que ele acreditava no Estado e ainda ia à missa, pedindo àquele pão, enquanto a Deus pedia justiça, dormindo a rezar ao pé da fogueira, que ainda haveria de lamber, convulsa, a Terra inteira. E prosseguia em suas críticas às crenças de Marcos, destacando que este abençoava a cruz que lhe enclavinhava os pés e que precisaria ser parvo para ainda crer que Moisés tomara indigestões de maná no deserto, ou nos judeus atravessando o Mar Vermelho aberto e, irônico, afirmava que, estando às portas do Natal, quem sabe aquele desgraçado não teria a ventura de o céu mandar-lhe um faisão recheado. Diante de tantas imprecações, Patrício perguntava se os céus ou Deus teriam feito algum mal ao seu interlocutor, o qual respondia que não se queixava, mas negava o bíblico mistério, que fora buscar o barro ao pó de um cemitério, não aceitando um ser que criava para depois matar, ao invés de manter uma Terra bailarina eternamente em flor (ARTAGÃO, 1936, p. 8-9).

Provocando Marcos a respeito de suas crenças, Patrício afirmava que lera Kant, ao passo que o outro se dedicava a Bakunin. Aquele respondia em desafio que ele lia um revoltado e o outro, um pedante, e perguntava se o 
conhecido não iria concordar que, quando permaneceram num catre de hospital, suas visões estavam muito mais ligadas a uma bomba e à ponta de punhal, ou questionava ainda se, na mesma situação, em noites hibernais, ouvindo o coração, como um martelo de aço a forçar uma porta, não teria dado um pontapé na velha crença morta. Mantendo o discurso antirreligioso, perguntava ao outro que também era pobre e se vestia como ele, por que não dava ao diabo a sua crença em Cristo. Voltando ao tema do tratamento hospitalar, associava a religião às desigualdades sociais, perguntando se seria normal que um nobre e gordo ratoneiro, só por ter dinheiro, lucrasse ainda mais com o roto cobertor de um triste lazarento e, mantendo o tom de revolta, exclamava que todos deveriam seguir avante, além da barricada, de onde romperia a nova madrugada (ARTAGÃO, 1936, p. 9-10).

Ainda manifestando suas ideias anticlericais, Mario de Artagão, através do personagem Marcos, questionava as "lendas do evangelho", afirmando que, com mil anos, um livro sempre seria "velho". Sobre o mesmo tema, referiase ao "livro das necroses", o compêndio secular de todas as nevroses, caruncho brutal de trágicas matanças que, com o gládio, sangrava o peito das crianças. Considerava a bíblia ainda como um livro que perturbava e era fantasista, que era surdo a um rouxinol, mas fazia falar um burro e parar o sol. Manifestava também sua descrença integrada à crítica de fundo social, declarando que Cristo pregara os códigos supremos num mundo muito diferente daquele em que eles estavam, não havendo lugar para viver pelo perdão, nas forjas e nos cais, nas gargantas das minas, no hálito letal das negras oficinas. Apontava que, em tais locais, o homem, a ulular, não vivia de perdão, precisando, ao invés disso, de mais ar, luz e pão. E complementava, argumentando que Jesus não tivera de enfrentar a cainçalha feroz da agiotagem moderna, esse inimigo audaz, impassível, viscoso, usurpador e voraz que vivia da usurpação do pobre que moirejava nas mesmas condições de um chacal que farejava as podridões (ARTAGÃO, 1936, p. 11-14).

Ambos continuavam debatendo, cada qual com suas convicções, até o encerramento da conversa quando se separavam, para só voltar a um novo encontro em outro capítulo do livro. Mas, antes de tal desfecho, Marcos faria uma longa peroração acerca das desigualdades sociais presentes nas vivências humanas desde os mais remotos tempos, mas que teriam se agravado na contemporaneidade. Lá estavam as condições de dependência social da antiguidade, do feudalismo medieval e das relações capitalistas de produção, notadamente a partir da Revolução Industrial, retratando um mundo onde os pobres não tinham vez nem voz. Assim, as preocupações de natureza social de Mario de Artagão se faziam presentes nas palavras de Marcos, primeiramente traçando um breve histórico desde os povos antigos até o imperialismo da virada do século XIX:

Os sonhos da Judéia! Horizontes sem asa, Que não iam além das campas de Gerasa! Nesses tempos de hipnose um rude assalariado Só conhecia o Templo e as relhas de um arado! Quisera vê-lo cá, nesta imensa agonia, A rilhar, soluçando, o pão de cada dia! Um mundo patriarcal! Um punhado de servos Sem a nossa revolta e sem os nossos nervos! Onde havia por lá os corações enfermos Que adoecem de tédio... inda antes de vivermos?! Guindastes anormais! Crepitações elétricas! O infinito da linha; as torvas linhas métricas Que varam o deserto e os matagais incultos Deixando pela estrada os corpos insepultos! Chispas em redemoinho, o fumo que sufoca E nos trás um sabor de sangue vivo à boca! Saturnismos fatais! Os mastodontes de aço Com os dentes da grelha a rir do nosso braço! Monopólios! Cartéis! As maltas industriais Talhando o mapa-mundi em pingues sucursais! As casas de penhor! A doirada canalha Que vê num barco o leito... e não vê a fornalha! A sôfrega avidez de bocas de criança, Mastigando de longe, em visões de faiança, Os restos que um nababo atira aos seus lacaios! (ARTAGÃO, 1936, p. 15-16)

Mantendo o mesmo tom, através da fala de Marcos, Mario de Artagão lembrava as desigualdades sociais desde a travessia das caravelas na época moderna até a massificação da exploração dos trabalhadores com a consolidação do capitalismo:

O mar-alto a rugir! A luta dos catraios Levando para o fundo o pescador indômito, Que lança para o céu a praga, como um vômito! A atroz terceira classe infecta dos porões! Um mineiro sem ar, na treva, aos apalpões! A guerra!... A guerra, enfim! A loba insaciada, Que derruba um herói, de borco, na escalada! E que são os heróis?! São sempre os nossos filhos, Que inda levam na boca o cheiro dos junquilhos Que uma noiva atirou à beira dos caminhos! Morrem a cantar, como os rouxinóis nos ninhos! E quem foi que os matou?... O Capital-Falperra, Sem entranhas, feroz, que manda para a guerra A mocidade em flor!... Sangue das nossas veias! Mas ele, o Parasita, arrotando nas ceias Um carnudo salmão comprado a peso de ouro, Bolsista, ladravaz, comensal do Tesouro, Enquanto o sangue espirra e golfa na trincheira, Lê os jornais... sorri... dá balanço à carteira, Consulta o Deve-e-Haver... depois queima um charuto, E dorme, regalado, um grande sono, o bruto! Quer tudo! Também quer que o bom Deus o proteja... 
Por isso, matinal e a pé, vai sempre à Igreja! Que lhe importa saber se o verbo amar é frouxo Quando o conjuga um lábio enregelado e roxo?! (ARTAGÃO, 1936, p. 16-17)

Os argumentos de Marcos foram tão contundentes que até o crédulo Patrício, num estado de semiembriaguez, acabaria dando razão a ele. Diante disso, Marcos passava a instigar Patrício, dizendo que ele não poderia vacilar, lembrando-lhe várias das chagas sociais que os cercavam, sintetizando toda aquela ira na figura de um "grotesco burguês", um "ricaço qualquer", que insultava a sua miséria e roubava a sua mulher. Das palavras, Marcos passava aos atos, deixando aparecer em suas mãos uma bomba, ao que reagia o companheiro, perguntando se ele havia ensandecido, recebendo por resposta que aquela peça tão bonita era um presente real naquela data de Natal, constituindo uma forma de manifestar a aversão às podridões que afligiam a humanidade. Diante das palavras e das intenções de Marcos, Patrício, escondendo a bomba, medroso e com um mau pressentimento, deixava seu interlocutor na tasca e desaparecia na escuridão da noite que vinha caindo (ARTAGÃO, 1936, p. 18-19).

No segundo capítulo, chamado "A caminho do cais", o cenário se deslocava, aparecendo apenas Patrício como o protagonista que encontrava figurantes pelo caminho. A cidade começava a se iluminar e Patrício refletia sobre as ansiedades, angústias e pavores que o atormentavam. Enraivado e conturbado pela dúvida, escondia-se nas sombras de uma viela, a ruminar as palavras de Marcos que contestavam suas crenças e lembravam que perdera sua amada por causa de sua condição de pobreza. Um espírito de vingança passava a tomar conta de Patrício, contrastando com o ambiente do centro da cidade no qual chegara e onde tudo flamejava numa formidável explosão de alegria. Dominado pelo delírio e a febre trágica da loucura, passava a comparar-se a Jesus que expulsara os vendilhões do templo, só que ele, ao invés do chicote, tinha a bomba que fulminava. A cada canto, Patrício via riquezas sem fim que só aguçavam a insatisfação com sua pobreza, de modo que, alucinado, passava a espreitar a hora do crime, olhando ao redor e buscando coragem para perpetrar o ato terrorista (ARTAGÃO, 1936, p. 21-24).

À procura de um escopo, o personagem do livro de Artagão circunvagava o olhar por uma praça iluminada, observando a bolsa de valores, os ricos e os financistas, alvos ideias de sua ensandecida ira, mas era detido pela visão de um mendigo que, à porta de um hotel, vendia bugigangas, contra o qual não quis atentar. Diante do contratempo, Patrício tornejava a praça, chegando a uma rua larga de edifícios ciclópicos, com cafés, cassinos, bares e cabarés, o que mais uma vez parecia o local ideal para o atentado, entretanto, a visão de uma prostituta, lembrava-lhe dos sofrimentos da vida, detendo mais uma vez seu tresloucado ato. Então ele seguia rua abaixo, chegando a um escaparate luxuoso cheio de guloseimas e, diante de tão impressionantes pratos, a fome apertava impulsionando sua raiva, levando-o a arrancar a bomba da algibeira e a levantar o braço para jogá-la, mas, mais uma vez era detido, agora pela presença de duas crianças, também esfaimadas para as quais daria sua última moeda, visando amainar o mal que as afligia. Vencido pelas circunstâncias, Patrício desistiria, tomando o caminho do cais e, chegando ao parapeito, num impulso irresistível, arremessaria ao mar a bomba que se arrebentou na aresta de uma rocha, numa explosão violentíssima. Entretanto, um fiscal o espreitava nas trevas, prendendo-o e chamando-o de bandido e ladrão (ARTAGÃO, 1936, p. 24-29).

"Mar alto" era o título do próximo capítulo que trazia as reflexões e vivências de Patrício na prisão, tendo sofrido vinte anos de degredo e submetido a trabalhos forçados. Lamentava a falta de sorte, pois havia lançado a bomba com o cais deserto e em direção ao mar, de modo que se não fosse a "rocha maldita", jamais teria sido aprisionado. Ainda que resignado por tantos anos de tormentos, amarguras e torturas, não deixava de considerar-se injustiçado, pois fora condenado apesar de inocente. Finalmente, o último capítulo, "De regresso à mansarda", retratava o reencontro de Marcos e Patrício, envelhecidos, duas décadas depois. Era, mais uma vez uma noite de Natal carregada de neve e frio. Amargurados, os amigos conversaram a respeito da chegada à velhice, mas, inevitavelmente, o diálogo descambaria para o assunto da prisão de Patrício, motivada pela bomba que Marcos lhe dera, diante do que, este insistia fervorosamente pelo perdão daquele. Ocorreria uma inversão de expectativas, pois, já ao final da vida, era Marcos quem apelava para a fé, justificando que muito aprendera com os sacrifícios do amigo, ao passo que Patrício se revelava cético, tendo em vista os sofrimentos pelos quais passara. No último ato, Marcos clamava pelo perdão, como deveria ser característico dos cristãos e convidava o companheiro para entrar numa igreja. Patrício, por sua vez, indeciso e a soluçar, afirmava que já não sabia rezar, entretanto, sonâmbulo, automático, deixava-se empurrar pelo amigo e os dois religiosamente desapareciam pelo portal da ermida (ARTAGÃO, 1936, p. 31-43).

Dessa maneira se encerrava Feras à solta, marcada pelas típicas contradições da própria humanidade. Ainda que fosse um ardoroso monarquista, Antônio da Costa Correia Leite Filho, desde seus primeiros trabalhos, sustentou certos pendores contrários à ampla predominância da religião católica. A princípio, tal pensamento poderia ser considerado uma significativa incoerência, pois como seria compatível sustentar ideias monárquicas e de defesa de um país que tivera uma 
constituição que previa o catolicismo como religião oficial e, ao mesmo tempo, manifestar-se antagonicamente em relação a tal religiosidade. Entretanto, a explicação se dá a partir da perspectiva pela qual vários pensadores e políticos da época monárquica, apoiavam ardorosamente um ideário anticlerical e mesmo contrário ao oficialismo religioso, como foi o caso de muitos dos seguidores do liberalismo, como o próprio Mario de Artagão (ALVES, 2011, p.55). Além disso, o anticlericalismo do autor não poderia ser confundido com ateísmo, como bem deixava claro o conjunto de sua obra. Do mesmo modo, sua revolta com as desigualdades sociais, retratando as agruras da pobreza que não vivera na carne, mas pudera observar nos diversos lugares em que estivera, não precisava significar uma aproximação com tendências ideológicas mais extremistas, monarquista convicto que era.

Assim, a obra derradeira de Mario de Artagão, Feras à solta, serviria para observar um fragmento de seu pensamento presente em outros de seus livros, manifestando um espírito revoltado em relação ao clericalismo e às mazelas sociais. As idas e voltas ao longo do tempo entre a fé e o ceticismo dos dois personagens revelavam as próprias idiossincrasias do país natal do autor, muitas vezes marcadas pelo clericalismo e a temporalidade em diversas facetas da vida pública e privada. O fato de politicamente ser identificado com a monarquia, numa convicção que lhe custaria inclusive o afastamento de sua pátria, não impedia que o poeta também pudesse militar nas ideias anticlericais, assim como, mesmo sendo um homem rico, não deixasse de ponderar quanto às injustiças de ordem social. Afinal Artagão associava em seu ideário monarquia, darwinismo científico, revolta social e contrariedades em relação à Igreja. Naquela virada de século ele estudara em lugares diferentes e lera de muitas fontes diferenciadas, vindo a metabolizar, sintetizar e mesmo amalgamar princípios que vieram a nortear seu modo de pensar (ALVES, 2011, p. 57-58).

Afastado das ardorosas lutas políticas da época da militância monárquica, Mario da Artagão não iria abandonar suas convicções, fenômeno bem demarcado em vários necrológios publicados junto à imprensa portuguesa e brasileira, em agosto de 1937, por ocasião de seu falecimento, os quais enalteciam seu valor como intelectual e destacavam seu apego imutável aos princípios monarquistas. Tais ideias ficavam expressas mesmo que nas entrelinhas de Rimas pagãs, assim como o anticlericalismo e as denúncias pelas mazelas sociais afloravam bem mais evidentemente em Feras à solta.
Desse modo, nas mais de três décadas em que viveu em Portugal, o poeta continuava expressando suas crenças e opiniões adquiridas ao longo de sua vida. Ele conviveu com diferentes formas de ver e pensar as sociedades, assimilando-as, apreendendo-as e interpretando-as à sua maneira, resultando em ideais uniformes e/ou amalgamados que compuseram suas convicções, as quais inevitavelmente viriam a marcar a sua produção literária, fosse aquela elaborada na juventude ou ainda quando estava em seus estertores, resultando numa obra ímpar e particular no rol daquela intelectualidade que tanto serviu à expansão das inter-relações e intercâmbios culturais no âmbito luso-brasileiro.

\section{Referências}

ALVES, Francisco das Neves. A produção literária de um poeta sul-rio-grandense: uma breve incursão ao pensamento e à obra de Mario de Artagão. In: Cadernos literários. Rio Grande: Ed. da FURG, 2011. v. 19. p. 49-58.

ALVES, Francisco das Neves. O debate político "monarquia $\mathrm{x}$ república" no discurso de um intelectual sul-rio-grandense. In: Anais do XI Encontro Estadual de História. Rio Grande: FURG, 2012. p. 360-369.

ARTAGÃO, Mario de. Rimas pagãs. Lisboa: Oficinas da Sociedade Nacional de Tipografia, 1933.

ARTAGÃO, Mario de. Feras à solta. Lisboa: Gráfica Portuguesa, 1936.

BLAKE, Augusto Victorino Alves Sacramento. Dicionário bibliográfico brasileiro. Rio de Janeiro: Imprensa Nacional, 1900.

CESAR, Guilhermino. História da literatura do Rio Grande do Sul (1737-1902). 3. ed. Porto Alegre: Instituto Estadual do Livro; CORAG, 2006.

FREITAS, José Joaquim de Senna. Ao veio do tempo (ideias, homens e fatos). Lisboa: Antonio Maria Pereira-Livraria Editora, 1908.

MARTINS, Ari. Escritores do Rio Grande do Sul. Porto Alegre: Ed. da UFRGS, 1978.

NEVES, Décio Vignoli das. Vultos do Rio Grande. Rio Grande: Artexto, 1987.

SARMENTO, José. O grande exilado. In: Ilustração Portuguesa - edição semanal do jornal O Século, Lisboa, 22 abr. 1907, v. 3, n. 61 , p. 489-495.

SODRÉ, Nelson Werneck. História da imprensa no Brasil. 4. ed. Rio de Janeiro: Mauad, 1999.

VILLAS-BÔAS, Pedro. Notas de bibliografia sul-riograndense: autores. Porto Alegre: "A Nação", Instituto Estadual do Livro, 1974.

Recebido: 03 de janeiro de 2014 Aprovado: 03 de março de 2014 Contato: fnah@vetorial.net 